\title{
Infants' Characteristics and Skills: Dissolving the Nature/Nurture Dichotomy
}

\author{
Briseida Resende ${ }^{*}, 1$ \\ Orcid.org/0000-0001-5932-0189
}

${ }^{1}$ Universidade de São Paulo, São Paulo, São Paulo, Brasil

\begin{abstract}
According to an emergent group of researchers, systemic, relational and evolutionary thought is needed to understand the development of organisms' characteristics and competences. In this paper, we first introduce the prevalent view on the biological basis of behavior, based on the New Synthesis of Modern Biology. Next, we present the critical view of those who defend Extended Evolutionary Synthesis. The existing debate between the different perspectives is illustrated by studies on infants' sensorial capacities, attachment, and neonatal imitation. Possible interpretations, based on the theoretical approaches presented, lead to a reflection on the innate/acquired dichotomy: from the prevailing view, this dichotomy is overcome because the interaction between the innate and the acquired is being considered to explain the characteristics of living beings. A further reflection on the developmental processes involved in the emergence of behavior, on the concepts of what is learning and what is innate leads to the dissolution of this dichotomy.
\end{abstract}

Keywords: Development, human ethology, evolution, nature/nurture dichotomy.

\section{Características e Competências dos Bebês: Rompendo a Dicotomia Inato/Aprendido}

\section{Resumo}

Uma corrente emergente de pesquisadores vem defendendo que a compreensão sobre o desenvolvimento das características e competências dos organismos passa pela adoção de um pensamento sistêmico, relacional e também evolucionista. Com o objetivo de apresentar este pensamento, inicialmente discutimos a visão prevalente sobre as bases biológicas do comportamento, que se baseia na Nova Síntese da Biologia Moderna, e, a seguir, expomos a crítica colocada pelos defensores da Síntese Estendida da Evolução. Os debates entre as abordagens serão exemplificados por meio da apresentação de pesquisas sobre as capacidades sensoriais e estabelecimento de vínculo do bebê e a imitação neonatal. As interpretações possíveis, baseadas nas abordagens teóricas apresentadas, desembocam em uma reflexão sobre a dicotomia inato/adquirido: pela visão prevalente, esta dicotomia está superada porque

* Mailing address: Universidade de São Paulo, Departamento de Psicologia Experimental, Instituto de Psicologia, Av. Professor Mello Moraes, 172, São Paulo, SP, Brazil 05508-030. Phone: 5511 3091-1941. E-mail: briseida@usp.br

Support: Alunos do Laboratório de Etologia Cognitiva do Instituto de Psicologia (IP) Universidade de São Paulo (USP); Ana Maria Almeida Carvalho, Patrícia Izar, Departamento de Psicologia Experimental do IP USP. 
a interação entre o inato e o adquirido vem sendo considerada para explicar as características dos seres vivos. Uma reflexão aprofundada sobre os processos de desenvolvimento envolvidos na emergência do comportamento ressignifica, no entanto, os conceitos de inato e aprendido, levando à dissolução desta dicotomia.

Palavras-chave: Desenvolvimento, etologia humana, evolução, dicotomia inato/adquirido.

\section{Características y Habilidades de los Bebés: Rompendo la Dicotomía Innato /Aprendido}

\section{Resumen}

Una corriente emergente de investigadores viene defendiendo que la comprensión del desarrollo de los carácter y competencias de los organismos implica la adopción de un enfoque sistémico, relacional y evolucionista. Con el fin de presentar este argumento, en principio discutiremos la visión predominante sobre las bases biológicas del comportamiento, soportada en la Nueva Síntesis de la Biología Moderna y, a continuación, expondremos la crítica propuesta por los partidarios de la Síntesis Evolutiva Extendida. El debate entre los enfoques será ejemplificado a través de la presentación de investigaciones sobre capacidades sensoriales, el establecimiento del apego e imitación neonatal. Las posibles interpretaciones desde cada uno de los enfoques teóricos presentados desembocaran en una reflexión sobre la dicotomía innato/ adquirido: el punto de vista predominante sostiene que esta dicotomía se supera cuando se consideran las interacciones innato-adquirido. Una reflexión profunda sobre los procesos de desarrollo, involucrados en la emergencia del comportamiento, conduce a la disolución de la dicotomia innato-aprendido.

Palabras clave: Desarrollo, etología humana, evolución, dicotomía innato/adquirido.

According to modern science mainstream view, organisms develop from genetic inheritance, the genotype, and some plasticity is admitted to the traits which compose an organism's phenotype, which depends on environmental interaction. This view is based on the New Synthesis of Modern Biology, orNeo-Darwinism, which unified the concepts of evolution through Natural Selection and genetics (Mayr, 1998). However, there is an emerging group of researchers who are standing up for the idea that a systemic and relational thought accounts for the emergence of traits and abilities, and must therefore be included in the evolutionary models (Laland et al., 2014; Oyama, Grifiths, \& Gray, 2001). Development begins when the organism comes into being, starting in the embryonic stage, and ends when the organism dies (and not when it reaches sexual maturity): thus Natural Selection acts on organisms in development, and not on a finished form.
In this essay, I will introduce this emerging thought, emphasizing the debate in the field of Developmental Psychology, particularly regarding infant skills. Due to this one being a critical review, the debate between traditional and eminent authors in the field of Developmental Psychology and Evolution is brought forward. In Brazil, the discussion on Developmental Systems is quite limited, even though some researches on child development refer to the Nature/Nurture dichotomy and the process of overcoming it (e. g., Servilha \& Bussab, 2015) and to the twoway interaction between the individual and their culture (Borges \& Salomão, 2015). The perspective presented here contributes to a better planning of future studies upon infant skills, and how to interpret their results.

The biological bases of behavior according to the New Synthesis of Modern Biology are introduced, followed by the criticism placed by advocates of the Extended Evolutionary 
Synthesis. Then, researches about infant's sensory skills, attachment, and neonatal imitation will be presented, as well as the possible interpretations from both theoretical perspectives, leading to a reflection on the nature/nurture dichotomy and its dissolution.

\section{Theoretical Overview: Organisms as Developmental Systems}

In his 1976 book, The Boys from Brazil, Ira Levin tells the story of a Nazi hunter who uncovers Dr. Josef Mengele's plan of creating genetic copies of Hitler, so as to create a new leader for the Nazi movement. Mengele was trying to ensure that the life history of each of these children replicated the Führer's. In the book, later turned into a movie, these boys present personality traits compatible with the dictator's personality. Levin based his work on the premise that several phenotypical possibilities could derive from a single genetic code, and that environmental conditions, especially life history, define the characteristics of adult individuals. As such, identical twins experiencing similar situations would develop essentially the same personality. It would then be possible to create a second Hitler, albeit not exactly the same one. In the public's imaginary, the idea of creating a clone as an individual exactly alike the one who originated it has been frequent in recent years. However, it is becoming increasingly clear to researchers that mapping the genome is not enough to allow us to predict how an organism works. Identical twins are not identical, even when sharing the same environment, be it in the uterus or after birth. After all, even if the environment looks identical, there will always be differences because the characteristics of an organism are determined by the constant interaction between structure and function. Therefore, it would be more correct to call them monozygotic twins, as pointed out by Francis (2011).

The traditional way to interpret the emergence of characteristics on organisms is in light of the Modern Synthesis of Biology. That is, the information would flow in only one direction, from the genes to the structure of proteins coded by them. The environment must be taken into consideration in this process, as genes would generate no structure in a vacuum: several factors interact with each other so that the characteristics of organisms emerge (Ridley, 2006). In case of mammals, these may be either intra or extra-uterine factors, such as, temperature, pressure, nutrient availability, presence or absence of light, presence of hormones. According to the Modern Synthesis of Biology, genes carry the overall design for the construction of the organism. Based on this design, one or another path of development may be followed, according to the environment. So, the gene-environment interaction would be considered within a context in which there is a separation between what is biological and what is environmental, maintaining the Nature $\mathrm{X}$ Nurture dichotomy. Thus, in Ira Levin's book, certainly a new Nazi leader with the same characteristics as the original would appear from embryos cloned from Hitler's genotype, if their life histories were kept as similar as possible to the original's. Although this view lays some emphasis on the environment, the genes would be the starting point and the defining factor in the development, following a structure $\rightarrow$ function direction.

In recent years, another interpretation of development has been growing, considering the existence of a bidirection of the elements involved in the emergence of the characteristics of organisms. This view has its origins linked to studies involving the development of organisms and can be associated to researchers who flourished in the mid-twentieth century, such as Zing Yang Kuo, Gilbert Gottlieb and Daniel Lehrman (Gottlieb, 2001; Honeycutt, 2011; Lehrman, 1953). More recently, new authors advocate in favor of this different conception of development and evolution (Jablonka, 2001; Laland et al., 2014; Oyama et al., 2001; Pigliucci \& Müller, 2010). Gottlieb (2001), for example, considers that the behavioral development of the individuals of a given species occurs according to probabilities, following certain rules. Thus, it would not follow an invariable, inevitable course: there would be a two-way direction in 
the structure-function relation, with reciprocal effects. The function would modify the course of development of the related structures. Following Gottlieb's reasoning, if sensory stimulation or motor movement are essential for establishing thresholds and maturity time in behaviors conventionally considered instinctive or innate, then the nature - nurture dichotomy evaporates, and we conclude that structure only occurs through function. Genes are expressed in response to internal and external stimuli, and react to environmental cues, pointing to the Structure $\leftrightarrow$ Function two-way direction. Organisms are then considered developing systems, and the dynamic and bidirectional interaction of the elements composing the systems - internal or external - defines the emerging characteristics.

James Gibson, Eleanor Gibson, and Anne Pick's ecological approach to the study of the development of perception establishes a dialogue with systemic thought (Gibson, 1968; Gibson \& Pick, 2000; Goldstein, 1981). According to Gibson and Pick (2000), in order to understand development, the focus must be on the adjustment between animal and environment. Development would neither be driven by mental representations, nor by an innate planning, because changes would be guided by multiple dynamic forces of development and by the activity of the organism itself. Removing the emphasis on the primacy of genes over behavior determination must in no ways be understood as excluding the importance of genotypical inheritance and giving emphasis to environmental importance. This is not the point. Both genetic and environmental determinism are excluded from this interpretation, as the developmental outcome will depend on the specific circumstances of each organism's history, which equally involves the variety of elements composing the system, whether biotic or abiotic.

According to the ecological approach to perception, there is plenty of information available in the environment, and perceptual learning occurs throughout development. Children are not born perceptually ready, and infants are not passive beings, flooded with stimuli. On the contrary, they are active beings who perceive and feel, actively seeking information about the world, and using it. According to Gibson and Pick (2000), perception guides action according to what the environment affords, action generates information perceived and used in further orientations, resulting in a continuous perception and action cycle. Each individual perceives through action and learns the affordances of objects, tasks, and their own body, in a dynamic process; objects, for instance, change according to luminosity, distance, and we keep a concept of that object. We accomplish specific tasks according to the size of our body, something that changes continuously throughout development: if the size changes, actions change, thus affecting the perceptions we have regarding our affordances and new performable actions. Infants learn about the world by perceiving, which always involves perception and action. A key concept in this perspective is the term affordance, coined by James Gibson to refer to the possibilities of action perceived by the individuals in their environment. Affordance is defined as the properties considered by the observer's point of view, referring to the complementarity of the animal with the environment. The perception of the affordances of bodies, tasks, objects, and people (i.e., of what can be done in the interactions involving these elements), promotes an infant's learning, guiding development.

The concept of affordances is used by Esther Thelen, who conducted a series of studies on motor development in infants, such as the development of "reaching" (Thelen, 2005). Thelen concluded movement was not "in" the baby (in terms of a fixed motor program, or a set of reflexes), but was contingent on the environment. That is, the exploration of the environment by the baby leads to the production of several types of space and force relations between objects and surfaces. Learning comes from the affordances of such relations, the coordination of relations using the body. The emphasis is removed from the cognitive maturation and mental representation and placed on perceptual practice and learning outcome. 
The purpose of this paper is to review human readiness to learn considering the systemic and evolutionary ecological perspective. Darwinian thought is used to explain the emergence and maintenance of populations' characteristics. According to this perspective, organisms vary within a group. Among these variants, some fit better than others and leave a greater number of descendants. This is the definition of Natural Selection, one of the main sources of evolution. Next generations will inherit not only the survivors' genes, but also environment, with its biotic and abiotic elements. Environment in this context should be understood in a broader sense, including the landscape, as well as the cellular environment surrounding the genome. The more stable the environment, the greater the probability the bidirectional interaction of these several levels of elements will result in stable characteristics from generation to generation, ensuring the manifestation of the considered species-typical behaviors (Bjorklund \& Pellegrini, 2001). Despite the great cultural differences, human infants are usually exposed to certain situations that are very similar, standardizing environments: gravity, pressure, social contact, attachment to caregiver. Thus, the course of development starting from conception follows universal human standards that characterize us as species, such as the development of bonds and language. Bateson and Laland (2013) go further, proposing that, if we consider extra genetic processes - such as cytoplasmic environment, environmental changes caused by traditions and culture, and ecological legacies - developmental processes begin even before conception. For this reason, ontogeny studies involve knowing the several inherited factors, and how the developmental environment has been gradually built throughout time. Both ontogeny and phylogeny are historical processes, occurring in different timescales that converge depending on the timeframe being considered.

When people are born, they and their species have already gone through a long process that started even before the conception, if we consider species evolution. From then on, how do perception, and the infants' readiness to learn and perceive environmental information, develop?

\section{Sensory Development: What Is Perceived by the Infant?}

The search for information is a basic and intrinsic motivation of all infants, and it is accomplished by perception-action cycles (Gibson \& Pick, 2000). Infants are naturally curious; they are able to detect sounds, odors, shapes; they are able to discriminate some tastes, to seek tactile sensations, to detect their own movements. When babies explore their surroundings, the consequences of their actions are rewarding. These skills can be used for designing research on perception and development.

In 1963, Robert Fantz, after studying infant behavior using innovative techniques he had developed, argued that newborns were able to see patterns, and not only blurs, contrary to the prevailing idea of the time. He has shown that all parts of the visual mechanism, from the cornea to the cortex, function somehow in newborns, developing throughout the first 6 months of life. He has also shown infants already prefer looking at faces stimuli.

Infant's smell perception was also studied using the preference paradigm. MacFarlane (1975), for example, showed that 6-day old infants - but not 2-day old infants - prefer turning their heads to breast pads previously used by their mothers. Porter and Winberg (1999) have shown that infants already prefer to head toward the nipple a few minutes after birth, and that there is a quick learned odor-based recognition.

Preference data was also used to investigate the intermodality between different senses. For example, Elizabeth Spelke (1976) developed a gaze preference experiment consisting in infants of approximately 4 months of age simultaneously watching two videos, from two events. At the beginning of the session, one of the videos' audio started playing. Infants chose watching the video corresponding to the audio, meaning they perceived the different components of the event: the sound and the image in this case. 
In recent years, Lewkowicz and his team have demonstrated that infants, including newborns, are able to associate voices with faces of people they have just met (Lewkowicz, Leo, \& Simion, 2010). They argue that multimodal perception is so vast at birth, that it allows human infants to integrate voice and face recognition of human and non-human primates. Babies would improve the perceived correlations regarding types of vocalization and visual cues. For example, in line with Gibson's theory, infants only start to detect coherence between speech and lip articulation at around 12 months of age (Lewkowicz, Minar, Tift, \& Brandon, 2015).

Eimas, Siqueland, Jusczyk, and Vigorito (1971) investigated infants' phonemic perception connecting pacifiers to a pressure measuring device, and quantified sucking. When infants were exposed to new sounds, they increased sucking. This set enabled identifying, for example, 1- to 4-month-olds' discrimination between similar sounds, such as /PA/ and /BA/. DeCasper and Fifer (1980) studied newborns' control of sounds according to the frequency they sucked a pacifier: a playback with their mother's voice reading a story followed a high sucking frequency, and a playback of a stranger female reading the same story followed low sucking frequency. Infants sucked at a higher frequency, showing a clear recognition and preference for their mothers' voice.

More recently, Beauchemin et al. (2011) measured newborns' brain activity (electroencephalogram; 8 to $27 \mathrm{~h}$ of age) and found that they already respond selectively towards their mother's voice: the newborn's adjustment shows that sucking is not merely a reflex, and that infants are able to control their environment using their behavioral repertoire. Kuhl, Conboy, Padden, Nelson, and Pruitt (2005) found that 6-month-old infants identified different ways of pronouncing vowels. After nearly 9 months, infants perceived fewer differences, increasingly responding only to the sounds of their native tongue. This restriction is in line with their ability to associate faces with voices. Newborns, besides preferring their mother's voice, are also sensitive to their native language prosody
(Mampe, Friederici, Christophe, \& Wermke, 2009): they are exposed to their native language even before they are born and already reproduce some of its prosodic properties in their crying.

Human language is not limited to the comprehension of phonemes, and its affective component is very soon identified by infants. When talking to small children, adults use a speech characterized by an increase and expansion of the speech frequency range, and an exaggeration of the phrasal intonation limits (Papousek, Bornstein, Nuzzo, \& Papousek, 1990). It is known as Motherese, Caretaker speech, Child-directed speech, or Baby talk. Papousek et al. (1990) showed that 4-monthold infants prefer looking at the same picture of an adult when they hear an approval prosody speech, even if there are no recognizable words.

Some studies show that infants have broad sound perception skills at birth, fundamental for synchronizing with the caregivers (Nazzi, Floccia, \& Bertoncini, 1998; Vouloumanos \& Werker, 2007). At 6 to 9 months of age, they already prefer hearing their native language prosodic and phonetical speech (Jusczyk, Cutler, \& Redanz, 1993).

Simion, Regolin, and Bulf (2008) have shown that 2-day-old infants preferred looking at stimuli simulating the movement of biological forms, such as animals. They interpreted these results as an evidence of innate behavior, a questionable conclusion, since skills will always need to be developed. Nonetheless, newborns have a great capacity to differentiate, or to learn to differentiate, the living from the non-living. In spite of this, small infants are not able to follow a slow-moving object with their gaze (von Hofsten, 2009). But at 4 months of age, infants can grasp objects within their reach. They can plan this movement, as their hands start to close before the object is encountered. When they begin reaching successfully for stationary objects, infants can also grasp moving objects. According to von Hofsten, at 18 weeks of age, infants are already able to catch slow-moving objects. At 8 months, they are able to catch faster moving objects. 
Very soon, infants know what to expect about the physical world. Elizabeth Spelke, Reneé Baillargeon and their teams have conducted several experiments to check infants' knowledge about the physical world. They also used gaze preference and habituation/dishabituation paradigms (Baillargeon, 2008; Spelke, 1994). According to these studies, 11-month-old infants gaze longer when a smaller object pushes a toy further than when a similar but larger one does (Kotovsky \& Baillargeon, 1994). Spelke states that newborns have core cognitions about objects, actions, numbers, space and social partners, as an outcome of natural selection. Then development, an experience-dependent process, takes place (Izard, Sann, Spelke, \& Strer, 2009; Spelke \& Kinzler, 2007). However, these ideas are challenged by Spencer et al. (2009; see below). Newborns need to attach to their caregivers for survivor. Much has been discussed about nature and nurture involved in this process.

\section{Bonding and Tuning for Learning}

Even though newborns will accept anyone as a caregiver, they get more restrict throughout development. According to Tomasello (2003), the infant undergoes a cognitive revolution at around 9 months, consisting of: rejection of strangers, sharing of intentions, restriction of the perception of the sounds of different language in favor of their own. For Meltzoff and Gopnik (1993), this relates to the fact that humans, early in life, see the other as someone like themselves, a key factor for following development in our social environment, where culture and the accumulation of knowledge are fundamental (Tomasello, 2003). Perceiving others as similar beings is essential for the social integration sought by the human infant. Shared attention and shared goals are fundamental steps towards the possibility of learning by imitation and by teaching (Tomasello, 2003, 2011). For Hrdy (2009), the survival of ancestral infants was only possible due to allocare, in addition to maternal care. The human capacity to perceive the intentions and thoughts of those around them emerged to distinguish who would and who would not provide care. According to Meltzoff and Gopnik (1993), infants recognize others as beings like them when they are born. Face recognition is essential in this case. Fantz (1963) showed that infants of up to 5 days of age would rather look at stimuli with patterns. The preferred patterns were black-and-white human face schemes. Bushnell (2001) demonstrated that very little experience is needed for infants to be able to show a preference for their mothers' faces. However, the more they are exposed to the sight of their mothers, the more they prefer it.

Neonatal imitation allows newborns to see others as similar to themselves. Meltzoff and Moore (1977) state that newborns can repeat simple facial expressions: tongue protrusion, mouth opening and pouting. Meltzoff and Gopnick (1993) consider imitation as a key mechanism for the development of mind comprehension. Neonatal imitation has also been demonstrated in non-human primates. MyowaYamakoshi, Tomonaga, Tanaka, and Matsuzawa (2004) showed that 6-day-old chimpanzees present neonatal imitation, responding to human models. Ferrari et al. (2006) have demonstrated that rhesus monkeys younger than 7 days of age also responded to human models showing tongue protrusion, lipsmacking (a characteristic behavior performed by adults to make contact with young infants), opening and closing eyes, and opening hands. All of these authors highlight the importance of neonatal imitation for the infant's integration in the social group, stressing its evolutionary roots. Myowa et al. (2004) highlight it's innate. For Ferrari et al. (2006), neonatal imitation relates to the affiliative gestures with communicative functions, a very important feature for the survival of the primate infant (Tramacere \& Ferrari, 2016).

Neonatal imitation research benefitted from mirror neuron studies. These cells fire when an individual performs an action and when this same individual sees the action being performed (Iacoboni et al., 2005). According to Ferrari and Fogassi (2012), neonatal imitation is probably the most convincing phenomenon implying the direct influence of mirror neurons: a mechanism 
present at birth that enables infants to match some movement characteristics with their internal motor representation. If it takes place without any previous experience is still subject to discussion. For nativists, infants are born with it. Developmentalists wonder how it developed so as to be adjusted and working properly at birth.

Jones (2009) questions the interpretations of the results about neonatal imitation. According to her, with the exception of tongue protrusion, the results are not supported by evidence, since the original studies are not reproducible, or their results may be interpreted differently. Jones does not believe tongue protrusion is imitation. According to her, sticking their tongues out is how infants respond to interesting stimuli and, so, the repeating of the demonstrator's tongue-sticking is a coincidence. She believes a similar explanation must be applicable to the neonatal imitation seen in non-human primates, and that we must be careful in accepting the explanation that infants are born with the mirror system ready for use. By challenging beliefs on neonatal imitation and their explanations, Jones claims the ability to imitate is an experience-based process.

Even if there is no consensus on when skills emerged, we know that, from a very young age, infants adjust their behaviors to their caregivers' behaviors (e.g., Mendes, 2009). Neonatal imitation would be one of the first mechanisms allowing this adjustment. It could, then, be considered as a resource for obtaining care and as the starting point of bonding. According to Trevarthen (2011), newborns already coordinate the rhythms of their movements and their senses, and they can synchronize their movements to those of others, which he interprets as the perception of somebody else's objectives and feelings. This author claims humans do not imitate others only to act as them, but also to engage in a communicative and cooperative relation. In this interaction, heart rate would increase, there would be an adjustment of expressive acts and an emotional response of pleasure in the exchange of intentions. Infants of approximately 6 months of age can identify the emotions of adults from their body language, even when their faces are hidden (Zieber, Kangas, Hock, \& Bhatt, 2014).
For Hamlin, Wynn, and Bloom (2007), 6and 10-month-old infants already positively or negatively assess others based on their behaviors, which would be the basis of moral judgment (Hamlin et al., 2007). In these studies, infants watch a geometric shape trying to climb an elevation and was either helped, by being pushed up the elevation by another geometric shape (the "helper"), or hindered by a third geometric shape (the "blocker"), who pushed it down the elevation. Upon watching, the child could choose one geometric shape offered on a tray. The overwhelming majority preferentially chose the shape representing the helper over the one hindering the task. The authors consider those results the evidence of an innate ability of assessment of goodness. The team conducted other studies, always presenting similar interpretations of the found results: infants having an innate ability of distinguishing shapes that help from those that hinder, and, thus, consistently choosing the helping shapes. These studies are criticized by researchers who emphasize the importance of learning for the emergence of choices throughout development: distinguishing between shapes and preferring to choose the helping shape may be alternatively understood as a consequence of some details in the experimental procedure. For example, Scarf, Imuta, Colombo, and Haine (2012) have pointed out that the geometric shapes would exhibit reactions that could work as positive or aversive stimuli for the infant (e.g., upon reaching the top of the elevation, the shape would "wiggle", celebrating). Scarf et al. (2012) replicated the experiment, controlling the reactions of the shapes that might work as aversive or reinforcing stimuli for the infants, and found different results from Hamlin and collaborators. The children seemed to be reacting to the geometric shape's "wiggling", and not to the fact that they helped or hindered. The babies' evaluation is not a merely innate ability. The results by Hamlin and collaborators are more cautiously interpreted as a phenomenon arising from the environmental structure built by adults, who scaffold moral development (Sterelny, 2010).

Recognizing faces, voices, smells, movement, emotions, all indicate that the infant is 
ready to connect to others and strengthen bonds. These skills are at the basis of what comes next: socialization and integration to the human world, an essentially cultural world (Ingold, 2002; Kärtner, 2015; Rogoff, 2003; Tomasello, 2011). Tomasello (2003) claims the human comprehension of co-specifics as intentional agents allows the infant to acquire human cultural heritage. For him, the pathway of cognitive development usually followed by human infants would firstly go through the recognition of others as similar beings, a newborn skill. At around 9 months, the infant starts recognizing others as intentional subjects, sharing attention. From the first to the second year, the child starts sharing goals and, at 3 to 4 years, they can attribute intention to others, enabling they to learn through teaching, a fundamental step for culture integration.

By the end of the first year, the child, who is already able to engage in "turn" interactions with adults (e.g., adult vocalizes, child vocalizes), is increasingly motivated to explore cultural practices and tools (Trevarthen, 2011), and prefers specific social agents (Hamlin et al., 2007; Scarf et al., 2012). It is also in this phase that children usually start walking, a size related skill: in bipedal walking, there is a pendular movement which needs to be controlled for the sake of balance - the taller the person, the lower the frequency of pendular swinging (von Hofsten, 2009). Children are curious and they like to explore, being motivated to move; movement also has a social motivation (von Hofsten, 2009): children are always motivated to interact with others, from whom they receive care and affection, and with whom they can learn new things.

\section{Nature and Nurture: A Proposal for Dissolving the Dichotomy}

Humans are helpless at birth, with slow development and an extended childhood, a common feature at the Primate Order, especially enhanced in humans (Bjorklund \& Pellegrini, 2001). Babies attach to their caregivers, the caregivers find them attractive, thus an infant-adult bond develop. Konrad Lorenz (1993) postulated the existence of the Kinderschema (baby scheme), defined as our instinct of being attracted to childish characteristics. We find infants "cute" because of their round and big heads to the rest of the body, their big eyes and cheeks, their chubby limbs and small noses. Lorenz considered instincts as innate, immutable behaviors, and the instinct to care for whoever has the characteristics of infants would be highly adaptive in highly altricial species. The case of human beings is even more conspicuous, as we are the most altricial primate.

Quoting Kinderschema, Stephen J. Gould published an essay on the evolution of Mickey Mouse, whose shape became rounder and more gracious throughout the years, turning him into a more profitable product, as he was adjusted to public taste (Gould, 1989). Hinde and Barden (1985) wrote an amusing article about the attraction we feel for child-like features: they studied the "evolution of the teddy bear". Since its conception, around 1900, in reference to a photograph of President Theodore Roosevelt with a bear (thus, Teddy bear), the teddy bear had its proportions gradually changed to conform to the body scheme indicated by Lorenz. As it was with Mickey Mouse, the market gradually selected the more gracious product, what seems to fit into the idea of an infant care.

Morris, Reddy, and Bunting (1995) studied whether there was an age effect in the attraction towards cuter dolls. By comparing how children of different ages were attracted, they found that 6- and 8-year old children preferred teddy bears with childish features, but those from the younger sample (4 years) did not. The authors argue that the evolution of the teddy bear must have been decided by the parents, not by the children, because adults are the ones who buy and select these products, and they were the ones who were actually attracted by the infant-like features. Considering that small children would not really need to care for anyone, the authors find it reasonable that the instinct of taking care would appear only later in development. However, other authors state the instinct of caring does not suddenly emerge in a specific moment of life, as if it were activated by a clock. Each manifested behavior has a history of development, an epi- 
genetic process with a cascade of interactions with multiple levels of causation, from genes to environments (Spencer et al., 2009). More recently, Luo, Kendrick, Li, and Lee (2015) found that adults who have children are more attracted to children's photographs, particularly with children whose age is similar to theirs. All these findings add an explanatory complexity taking into consideration the phylogenetic and ontogenetic history.

The attraction to childish traits is a later accomplishment during childhood, but newborns show several skills already mentioned. According to Spelke and Kinzler (2007), infants are born with five systems of core knowledge (about objects, actions, numbers, space and social world) that enable the understanding of the physical and social world at birth. These authors defend an intermediate point of view between the extreme nativism (skills are determined by behavioral modules predetermined at birth and phylogenetically selected), and the extreme environmentalist position (human mind is a flexible, adaptable mechanism for discovering regularities in the experience, identified with the idea of a blank slate; Spelke \& Kinzler, 2007). Spencer et al. (2009) disagree, because, besides not solving nature/nurture dichotomy, this perspective is not a solution for understanding the origins of these skills: saying there is a set of skills present at birth, attributing their emergence to evolution and, therefore, to a genetic predisposition, would not explain the emergence of the characteristic in each individual. The fact that organisms have undergone evolutionary processes would not withdraw the need to explain these developmental processes, as they shape behavior.

Spelke and collaborators' point of view maintains the nature/nurture dichotomy, but considers that from the five core knowledge systems the diversification of knowledge occurs, through experience. Spencer and collaborators' perspective promotes the complete rupture between what is innate and what is learned: it is not about defending the blank slate, or the rupture with evolutionary history; it is about acknowledging, first, that development has also been selected, it does not begin at birth, and it is a process involving multiple relations of cause and effect, not always predicted. There are, thus, many factors influencing the paths of development (Spencer et al., 2009). For example, genes may or may not be activated according to temperature and availability of nutrients; a bird's vocalization depends on its experience hearing its own call within the egg (Gottlieb, 2001); infants will walk sooner or later according to their height (von Hofsten, 2009); a child's language development already starts in the womb, by exposure to the native tongue (Jones, 2009). Thus, newborn' skills result from a complex, bidirectional process: the causes of behavior can be investigated and understood in some aspects, but we cannot predict with certainty the paths that will be taken during development. We can only make a probabilistic estimate (Gottlieb, 2001). We can explain, but we cannot predict exactly what will happen. Thus, we cannot recreate Hitlers, or Darwins, or Einsteins.

Human newborns, far from being born as blank slates, identify faces, sounds, odors, and they perceive movement and react to the properties of the physical and social world. On the contrary. They are equipped for survival. That's why they must identify their caregiver and the world they live in, behaving as an active agent for bonding with the closest adults. A ready to learn newborn is not equivalent to a newborn with fixed skills selected throughout evolution. There is a subtle difference: before birth, development was already under way, and, therefore, the innate skill (present at birth) is the outcome of a process and many different paths may be followed. However, since not only genes are inherited, but also environment in a broad sense, the developmental path from each human leads to behavioral and cognitive traits bearing a remarkable resemblance within our species. Nonetheless, the simple act of walking, for example, reflects each person's history of development, with their distinct physical and cultural environments (Ingold, 2002). Thus, innate is not a synonym of genetically predetermined: it is the outcome of a geneenvironment interaction, without priority of one 
or the other. Social interactions are central to the healthy development of children. Very young infants have skills to connect with the adults who will ensure them affection, food, protection, and all kinds of care. They come to the world acting and perceiving, as they were already doing inside the womb, since development started.

\section{References}

Baillargeon, R. (2008). Innate ideas revisited: For a principle of persistence in infants' physical reasoning. Perspectives on Psychological Science, 3, 2-13. doi: 10.1111/j.1745-6916.2008.00056.x

Bateson, P., \& Laland, K. N. (2013). Tinbergen's four questions: An appreciation and an update. Trends in Ecology \& Evolution, 28(12), 712-718.

Beauchemin, M., González-Frankenberger, B., Tremblay, J., Vannasing, P., Martínez-Montes, E., Belin, P., ...Lassonde, M. (2011). Mother and stranger: An electrophysiological study of voice processing in newborns. Cerebral Cortex, 21(8), 1705-1711. doi: 10.1093/cercor/bhq242

Bjorklund, D., \& Pellegrini, A. (2001). The origins of human nature: Evolutionary developmental psychology. Washington, DC: American Psychological Association.

Borges, L. C., \& Salomão, N. M. R. (2015). Concepções de desenvolvimento infantil e metas de socialização maternas em contexto não urbano. Estudos de Psicologia (Natal), 20(2), 114-125.

Bushnell, I. W. R. (2001). Mother's face recognition in newborn infants: Learning and memory. Infant and Child Development, 10, 67-74. doi: 10.1002/icd.248

DeCasper, A., \& Fifer, W. (1980). Of human bonding: Newborns prefer their mothers' voices. Science Magazine, 208(4448), 1174-1176.

Eimas, P. D., Siqueland, E. R., Jusczyk, P., \& Vigorito, J. (1971). Speech perception in infants. Science, 171, 303-306. doi: 10.1126/ science. 171.3968 .303

Fantz, R. L. (1963). Pattern vision in newborn infants. Science, 140(3564), 296-297. doi: 10.1126/ science. 140.3564 .296

Ferrari, F., \& Fogassi, L. (2012). The mirror neuron system in monkeys and its implications for social cognitive functions. In F. B. M. de Waal \& P. F. Ferrari (Eds.), The primate mind:
Built to connect with other minds (pp. 13-31). Cambridge, MA: Harvard University Press.

Ferrari, P. F., Visalberghi, E., Paukner, A., Fogassi, L., Ruggiero, A., \& Suomi, S. J. (2006). Neonatal imitation in rhesus macaques. PLoS Biology, 4(9), 1501-1508. doi: 10.1371/journal. pbio.0040302

Francis, R. C. (2011). Epigenetics: How environment shapes our genes. New York: W.W. Norton.

Gibson, E., \& Pick, A. (2000). An ecological approach to perceptual learning and development. Oxford, UK: Oxford University Press.

Gibson, J. (1968). What gives rise to the perception of motion? Psychological Review, 75(4), 335-346.

Goldstein, E. B. (1981). The ecology of J. J. Gibson's perception. Leonardo, 14(3), 191-195.

Gottlieb, G. (2001). A developmental psychobiologicalisêpSystems view: Early formulation and current status. In S. Oyama, P. E. Griffths, \& R. D. Gray (Eds.), Cycles of contingency: Developmental systems and evolution (pp. 41-54). Cambridge, MA: Massachusetts Institute of Technology Press.

Gould, S. J. (1989). O polegar do panda: Reflexões sobre história natural (pp. 83-94). São Paulo, SP: Martins Fontes.

Hamlin, J. K., Wynn, K., \& Bloom, P. (2007). Social evaluation by preverbal infants. Nature, 450, 557-559. doi: $10.1038 /$ nature 0628

Hinde, R., \& Barden, L. (1985). The evolution of the teddy bear. Animal Behaviour, 33(4), 13711372. doi: 10.1016/0003-3472(95)80022-0

Hrdy, S. B. (2009). Mothers and others: The evolutionary origins of mutual understanding. Cambridge, MA: Belknap Press.

Honeycutt, H. (2011). The "enduring mission" of Zing-Yang Kuo to eliminate the nature-nurture dichotomy in psychology. Developmental Psychobiology, 53(4), 331-42. doi: 10.1002/ dev.20529

Iacoboni, M., Molnar-Szakacs, I., Gallese, V., Buccino, G., Mazziotta, J., \& Rizzolatti, G. (2005). Grasping the intentions of others with one's own Mirror Neuron System. PLoS Biology, 3(3), 529-535. doi: 10.1371/journal.pbio.0030079

Ingold, T. (2002). Evolving skills. In H. Rose \& S. Rose, Alas poor Darwin (pp. 225-246). London: Vintage. 
Izard, V., Sann, C., Spelke, E., \& Strer, A. (2009). Newborn infants perceive abstract numbers. PNAS, 106(52), 10382-10385. doi: 10.1073/ pnas.0812142106

Jablonka, E. (2001). The systems of inheritance. In S. Oyama, P. E. Griffths, \& R. D. Gray (Eds.), Cycles of contingency: Developmental systems and evolution (pp. 99-116). Cambridge, MA: Massachusetts Institute of Technology Press.

Jones, S. (2009). The development of imitation in infancy. Philosophical Transactions Royal Society Biological Sciences, 364, 2325-2335. doi: 10.1111/j.1467-9280.2007.01945.x

Jusczyk, P.W., Cutler, A., \& Redanz, N. (1993). Infants' preference for the predominant stress patterns of English words. Child Development, 64(3), 675-687.

Kärtner, J. (2015). The autonomous developmental pathway: The primacy of subjective mental states for human behavior and experience. Child Development. doi: 10.1111/cdev.12377

Kotovsky, L., \& Ballargeon, R. (1994). Calibration-based reasoning about collision events in 11-month-old infants. Cognition, 51, 107-129.

Kuhl, P., Conboy, B., Padden, D., Nelson, T., \& Pruitt, J. (2005). Early speech perception and later language development: Implications for the "Critical Period". Language Learning and Development, 1, 237-264. doi: 10.1111/j.1751228X.2011.01121.X

Laland, K. N., Uller, T., Feldman M.W., Sterelny, K., Müller, G., Mokzek, A., ...Strassmann, J. (2014). Does evolutionary theory need a rethink? Yes, urgently. Nature, 514, 161-164. doi: $10.1038 / 514161 \mathrm{a}$

Lehrman, D. (1953). A critique of Konrad Lorenz's theory of instinctive behavior. The Quarterly Review of Biology, 28, 337-363.

Levin, I. (1976). Os meninos do Brasil. Rio de Janeiro, RJ: Livraria Francisco Alves.

Lewkowicz, D., Leo. I., \& Simion, F. (2010). Intersensory perception at birth: Newborns match nonhuman primate faces and voices. Infancy, 15(1), 46-60.

Lewkowicz, D., Minar, N., Tift, A., \& Brandon, M. (2015). Perception of the multisensory coherence of fluent audiovisual speech in infancy: Its emergence and the role of experience. Journal of Experimental Child Psychology, 130, 147-162. doi: 10.1016/j.jecp.2014.10.006
Lorenz, K. (1993). Os fundamentos da Etologia (P. M. Cruz \& C. Alberts, Trans.). São Paulo, SP: Editora da Universidade Estadual Paulista «Júlio de Mesquita Filho».

Luo, L., Kendrick, K., Li, H., \& Lee, K. (2015). Adults with siblings like children's faces more than those without. Journal of Experimental Child Psychology, 129, 148-156. doi: 10.1016/j. jecp.2014.09.003

MacFarlane, A. (1975). Olfaction in the development of social preferences in the human neonate. Ciba Foundation Symposium, (33), 103-113.

Mampe, B., Friederici, D., Christophe, A., \& Wermke, K. (2009). Newborns' cry melody is shaped by their native language. Current Biology, 19(23), 1994-1997. doi: 10.1016/j.cub.2009.09.064

Mayr, E. (1998). O desenvolvimento do pensamento biológico (pp. 597-636). Brasília, DF: Editora da Universidade de Brasília.

Meltzoff, A., \& Gopnick, A. (1993). The role of imitation in understanding persons and developing theories of mind. In S. Baron-Cohen \& H. Tager-Flusberg (Eds.), Understanding other minds: Perspectives from autism (pp. 335367). Oxford, UK: Oxford University Press.

Meltzoff, A. N., \& Moore, M. K. (1977). Imitation of facial and manual gestures by human neonates. Science, 198, 75-77. doi: 10.1126/science.198.4312.75

Mendes, D. M. L. F. (2009). As expressões emocionais e o desenvolvimento inicial. In $\mathrm{M}$. L. Seidl-de-Moura, D. Mendes, \& L. Pessôa (Eds.), Interação social e desenvolvimento (pp. 71-86). Curitiba, PR: Editora CRV.

Morris, P., Reddry, V., \& Bunting, R. C. (1995). The survival of the cutest: Who's responsible for the evolution of the teddy bear? Animal Behavior, 50, 1697-1700. doi: 10.1016/00033472(95)80022-0

Myowa-Yamakoshi, M., Tomonaga, M., Tanaka, M., \& Matsuzawa, T. (2004). Imitation in neonatal chimpanzees (Pan troglodytes). Developmental Science, 7(4), 437-444.

Nazzi, T., Floccia, C., \& Bertoncini, J. (1998). Discrimination of pitch contours by neonates. Infant Behavior and Development, 21(4), 779784. doi: 10.1016/S0163-6383(98)90044-3

Oyama, S., Griffths, P., \& Gray, R. (2001). Introduction: What is developmental systems theory? In S. Oyama, P. E. Griffths, \& R. D. Gray (Eds.), Cycles of contingency: Developmental systems 
and evolution (pp. 1-12). Cambridge, MA: Massachusetts Institute of Technology Press.

Papousek, M., Bornstein, M., Nuzzo, C., \& Papousek, H. (1990). Infant responses to prototypical melodic contours in parental speech. Infant Behavior and Development, 13(4), 539-545. doi: 10.1016/0163-6383(90)90022-Z

Pigliucci, M., \& Müller, G. (2010). Elements of an Extended Evolutionary Synthesis. In M. Pigliucci \& G. Müller (Eds.), Evolution: The extended synthesis (pp. 3-17). Cambridge, MA: Massachusetts Institute of Technology Press.

Porter, R. H., \& Winberg, J. (1999). Unique salience of maternal breast odors for newborn infants. Neuroscience \& Biobehavioral Reviews, 23(3), 439-449. doi: 10.1016/S0149-7634(98)00044-X

Ridley, M. (2006). Evolução (3rd ed.). Porto Alegre, RS: Artmed.

Rogoff, B. (2003). Orienting concepts and ways of understanding the cultural nature of human development. In The cultural nature of human development (pp. 3-36). Oxford, UK: Oxford University Press.

Scarf, D., Imuta, K., Colombo, M., \& Hayne, H. (2012). Social evaluation or simple association? Simple associations may explain moral reasoning in infants. PloS One, 7(8), e42698.

Servilha, B., \& Bussab, V. S. R. (2015). Interação mãe-criança e desenvolvimento da linguagem: A influência da depressão pós-parto. Psico, 46(1), 101-109.

Simion, F., Regolin, L., \& Bulf, H. (2008). A predisposition for biological motion in the newborn baby. PNAS, 105(2), 809-813. doi: 10.1073/ pnas.0707021105

Spelke, E. (1976). Infants' intermodal perception of events. Cognitive Psychology, 8(4), 553-560. doi: 10.1016/0010-0285(76)90018-9

Spelke, E. S. (1994). Initial knowledge: Six suggestions. Cognition, 50, 431-445. doi: 10.1016/0010-0277(94)90039-6

Spelke, E. S., \& Kinzler, K. D. (2007). Core knowledge. Developmental Science, 10(1), 8996. doi: 10.1111/j.1467-7687.2007.00569.x
Spencer, J., Blumberg, M., McMurray, B., Robinson, S., Samuelson, L., \& Tomblin, B. (2009). Short arms and talking eggs: Why we should no longer abide the nativist-empiricist debate. Child Development Perspectives, 3(2), 79-87. doi: 10.1111/j.1750-8606.2009.00081.x

Sterelny, K. (2010). Moral nativism: A sceptical response. Mind \& Language, 25(3), 279-297.

Thelen, E. (2005). Dynamic systems theory and the complexity of change. Psychoanalytic Dialogues, 15(2), 255-283.

Tomasello, M. (2003). Origens culturais da aquisição do conhecimento humano. São Paulo, SP: Martins Fontes.

Tomasello, M. (2011). Human culture in evolutionary perspective. In M. Gelfand (Ed.), Advances in Culture and Psychology (pp. 1-51). Oxford, MA: Oxford University Press.

Tramacere, A., \& Ferrari, P. (2016). Faces in the mirror, from the neuroscience of mimicry to the emergence of mentalizing. Journal of Anthropological Sciences, 94(1-14). doi: 10.4436/JASS.94037

Trevarthen, C. (2011). What is it like to be a person who knows nothing? Defining the active intersubjective mind of a newborn human being [Special issue]. Infant and Child Development, 20(1), 119-135. doi: 10.1002/icd.689

Von Hofsten, C. (2009). Action, the foundation for cognitive development. Scandinavian Journal of Psychology, 50(6), 617-623. doi: 10.1111/j.1467-9450.2009.00780.x

Vouloumanos, A., \& Werker, J. (2007). Listening to language at birth: Evidence for a bias for speech in neonates. Developmental Science, 10(2), 159171. doi: 10.1111/j.1467-7687.2007.00549.x

Zieber, N., Kangas, A., Hock, A., \& Bhatt, R. (2014). Infants' perception of emotion from body movements. Child Development, 85(20), 675684. doi: $10.1111 /$ cdev. 12134

Received: 11/08/2016

$1^{\text {st }}$ revision: $26 / 10 / 2016$

$2^{\text {nd }}$ revision: $22 / 06 / 2017$

$3^{\text {rd }}$ revision: $11 / 10 / 2017$

$4^{\text {th }}$ revision: $06 / 11 / 2017$

Accepted: 12/11/2017

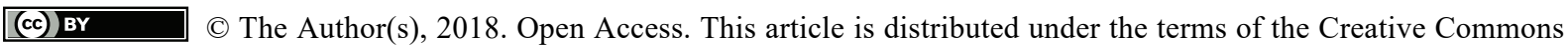
Attribution 4.0 International License (http://creativecommons.org/licenses/by/4.0/), which permits unrestricted use, distribution, and reproduction in any medium, provided you give appropriate credit to the original author(s) and the source, provide a link to the Creative Commons license, and indicate if changes were made. 